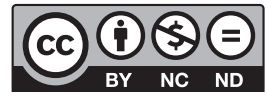

Estudos Teológicos foi licenciado com uma Licença Creative Commons Atribuição - NãoComercial - SemDerivados 3.0 Não Adaptada

http://dx.doi.org/10.22351/et.v60i3.4183

\title{
Sobre Justiça humana e a Justiça de Deus: UMA REFLEX̃̃O EM DIÁLOGO COM O PENSAMENTO TEOLÓGICO DE Vítor Westhelle ${ }^{1}$
}

\author{
On human justice and God's justice: \\ A reflection in dialogue with the theological thought of Vitor Westhelle
}

Roberto E. Zwetsch ${ }^{2}$

Resumo: A teologia de Vítor Westhelle nos desafia a reler permanentemente a teologia de Lutero e da Reforma, mas claramente a partir da perspectiva das pessoas que sofrem e lutam por recuperar a dignidade de viver num mundo marcado por injustiças, desigualdades e violência. Seu livro O Deus escandaloso (2006) é um dos mais extraordinários textos que escreveu sobre a teologia da cruz do Reformador, traduzido e publicado no Brasil em 2008. Nele, temos uma reflexão contextualizada no tempo e no espaço sobre a dimensão crítica da teologia e da igreja cristãs, sem a qual a fé cristã ou se torna cínica ou cai num vazio que a desfigura irremediavelmente. Neste artigo retomo um tópico do livro de Westhelle que trata da questão da justiça humana e da justiça de Deus, como tema atual e relevante para elaborarmos uma teologia de olhos abertos para o sofrimento humano, com os pés bem situados no chão da realidade ambígua e violenta em que vivemos, sem perder a dimensão do amor compassivo que liberta e traz alegria para as tribulações da nossa existência.

Palavras-chave: Justiça humana. Justiça de Deus. Teologia da cruz. Solidariedade libertadora.

Abstract: Vítor Westhelle's theology challenges us to reread Luther's theology and Reformation theology permanently, but clearly from the perspective of people who suffer and struggle to regain the dignity of living in a world marked by injustices, inequalities and violence. His book The Scandalous God (2006) is one of the most extraordinary texts he wrote on the theology of the cross of the Reformer, translated and published in Brazil in 2008. In it we have a contextualized reflection in time and space on the critical dimension of theology and Christian churches, without which the

\footnotetext{
1 O artigo foi recebido em 31 de outubro de 2020 e aprovado em 04 de dezembro de 2020 com base nas avaliações dos pareceristas ad hoc.

2 Pastor da IECLB, professor associado de Faculdades EST, membro do Grupo de Pesquisa Identidade Étnica e Interculturalidade do PPG de Faculdades EST, membro do Conselho Permanente do FMTL - Fórum Mundial de Teologia e Libertação. Agradeço à Lori Altmann pela leitura atenta e as oportunas sugestões incorporadas ao texto.
} 
Christian faith either becomes cynical or falls into a void that irretrievably disfigures it. In this article I return to a topic in Westhelle's book that deals with the issue of human justice and God's justice, as a current and relevant theme for us to elaborate a theology with eyes open to human suffering, with our feet well placed on the ambiguous and violent ground on which we live, without losing the dimension of compassionate love that liberates and brings joy to the tribulations of our existence.

Keywords: Human justice. God's justice. Theology of the cross. Liberating solidarity.

\section{Introdução}

A teologia, qua teologia crucis, não pode permanecer dentro das formas reconhecidas de discurso.

Vitor Westhelle

Não sofro esta dor como Cesar Vallejo. Não sofro agora como artista, como homem nem mesmo como simples ser vivo. Não sofro esta dor como católico, como maometano, nem mesmo como ateu. Hoje somente sofro. [...] Sofro sem explicação. [...] Hoje sofro, suceda o que suceda. Hoje sofro, nada mais. Cesar Vallejo

Se essas palavras de Cesar Vallejo fossem ditas hoje, em meio à pandemia global da Covid-19, talvez a entendêssemos muito bem. Ou não? E por uma ironia da literatura, ele intitulou esse texto da seguinte maneira: "Vou falar de esperança". Como é possível tal aparente contradição? Sofrimento, esperança? Como combinar essas duas realidades?

Um dos maiores canais de TV do Brasil vem exibindo ultimamente uma propaganda de seu jornalismo que traz fragmentos de falas de eminentes juristas e políticos brasileiros em que esses senhores afirmam a solidez das instituições brasileiras. Em vista da crise política e social que o país vive, defendem também que a "democracia brasileira sairá fortalecida". Nenhuma liderança feminina da política nacional foi chamada para se fazer ouvir na peça publicitária. Como tal, porém, ela padece de extraordinárias incongruências porque faz afirmações gerais, aparentemente definitivas, em relação à sociedade brasileira e suas instituições, mas sobre as quais não existe nenhum consenso e muito menos concordância. Quem pode afirmar - com segurança - de que a atual democracia brasileira seja sólida, forte e que as instituições estejam funcionando plenamente? Para não dizer que aquelas falas são um disparate, bastaria tomar como exemplo a descoordenação quase criminosa que o governo brasileiro imprimiu ao enfrentamento da pandemia da Covid-19 em 2020, causando situações que provocaram inutilmente o aumento de casos da contaminação do vírus (já passam de seis milhões ao escrever este texto) e um número assustador de mortes em todo o país (mais de 175 mil pessoas, desconsiderando muitas outras morbidades clínicas e sociais, entre elas, o avanço da matança de jovens negros por forças policiais e os 
casos recorrentes de feminicídio durante a pandemia). Isso sem trazer à discussão os inúmeros atos, decretos e mudanças administrativas que vêm sendo responsáveis pela consistente destruição do patrimônio público e democrático nacional, sem que as referidas "instituições" exerçam o papel limitador e de garantia da Constituição Federal, inúmeras vezes atacada, descumprida ou simplesmente ignorada.

Outro exemplo gritante que motiva a presente reflexão sobre a questão da justiça diz respeito a uma das principais leis que mostrou sua força, pertinência e solidez - esta sim - durante os últimos meses em que o Brasil e o mundo se viram diante da pandemia da Covid-19. A pandemia mudou completamente o cenário mundial e acarretou uma reviravolta no sistema econômico dominante, marcado pelo neoliberalismo e, no caso brasileiro, por sinais concretos de um ultraliberalismo que já compromete o presente e o futuro do país, não apenas em termos econômicos, mas também políticos, diplomáticos e socioculturais. Refiro-me ao SUS - Sistema Único de Saúde, reconhecidamente um dos sistemas de saúde mais justos e complexos do mundo porque universal e acessível a toda a população brasileira. ${ }^{3}$ Diante do que estamos vivendo com a persistência da pandemia, o crescimento do desemprego, o avanço da fome que já atinge mais de dez milhões de pessoas, a insegurança diante das medidas econômicas que vêm sendo tomadas sem resultados concretos para a população majoritária, o negacionismo que impera no centro do governo federal frente à pandemia e outros fatores que envolvem as relações internacionais brasileiras, o SUS, a instituição provisória do auxílio emergencial para amplas maiorias e algumas outras medidas pontuais trouxeram para o primeiro plano da política nacional questões que envolvem a compreensão do que seja justiça neste país, de modo particular, justiça social, obrigando até mesmo os setores mais conservadores da sociedade a se render a esse discurso que lhes é tão incômodo e alheio.

Esse tema desafiador para toda a população, principalmente, as maiorias mais empobrecidas, vulneráveis e abandonadas pelo serviço público - com a rara exceção do SUS, mesmo não sendo um sistema perfeito -, não pode deixar de impactar a reflexão teológica, se essa parte do fundamento bíblico-teológico do amor e da misericórdia divina revelados no evangelho. Justiça, justiça de Deus, fé e razão, sofrimento,

\footnotetext{
3 Lei no 8080: 30 anos de criação do Sistema Único de Saúde (SUS). Em 19/9/1990 foi assinada a Lei $\mathrm{n}^{\circ} 8080$ que dispõe sobre as condições para a promoção, proteção e recuperação da saúde, a organização e o funcionamento dos serviços correspondentes, instituindo o Sistema Único de Saúde (SUS). O SUS é um dos maiores e mais complexos sistemas de saúde pública do mundo, abrangendo desde o simples atendimento para avaliação da pressão arterial, por meio da Atenção Primária, até o transplante de órgãos, garantindo acesso integral, universal e gratuito para toda a população do país. Com a sua criação, o SUS proporcionou o acesso universal ao sistema público de saúde, sem discriminação. A atenção integral à saúde, e não somente aos cuidados assistenciais, passou a ser um direito de todos os brasileiros, desde a gestação e por toda a vida, com foco na saúde com qualidade de vida, visando à prevenção e à promoção da saúde. São princípios do SUS: universalidade, equidade, integralidade. Quanto à estrutura, a gestão das ações e dos serviços de saúde deve ser solidária e participativa entre os três entes da Federação: a União, os estados e os municípios. O SUS é composto pelo Ministério da Saúde, estados e municípios, conforme determina a Constituição Federal. Cada ente tem suas corresponsabilidades.

Fonte: $<$ http://bvsms.saude.gov.br/ultimas-noticias/3295-lei-n-8080-30-anos-de-criacao-do-sistema-unicode-saude-sus>. Acesso em: 30 out. 2020.
} 
dor e libertação, esses conceitos não são neutros do ponto de vista teológico. Dizem respeito a realidades humanas e espirituais que mobilizam a compreensão da fé cristã enquanto "confiança radical" (fiducia), como a compreendeu o reformador Martim Lutero. Para o reformador, tal confiança está alicerçada na palavra de Deus - no Evangelho - e no temor dela. Essa palavra irrompe através de palavras humanas, mas para nosso completo desconforto, vai "contra a correnteza dos sistemas dominantes, as regras do familiar, a lei da casa (oeconomia)", como escreveu Vítor Westhelle no seu livro $O$ Deus escandaloso ${ }^{4}$. Reportando-se a um comentário de Oswald Bayer numa carta de Lutero a Melanchthon em 1530, na qual o teólogo alemão afirma que a "verdade da fé não é comunicável como se fosse uma mercadoria", Westhelle acrescenta: "Ela não se enquadra nas regras normais pelas quais os regimes de verdade operam na filosofia, política, economia e igreja"s.

É por essa razão que entendo ser compromissivo - para a teologia cristã que se quer libertadora em nossa realidade brasileira e latino-americana - assumir o desafio posto pela demanda da justiça social, consequentemente, a luta pelo resgate da dignidade humana e hoje, também, ambiental como parte de sua tarefa nas comunidades de fé e na sociedade. Com esse intuito, valho-me aqui de um capítulo central no livro de Westhelle acima mencionado (capítulo 3: Deus contra Deus. A Reforma no passado e no presente), no qual ele retoma a teologia da cruz de Lutero de modo crítico e contextualizado afirmando que seu objetivo "é a tentativa de libertar a teologia do cativeiro dos modos dominantes de racionalidade, que não por coincidência estavam em sintonia com a jurisprudência e o raciocínio econômico dominantes" ${ }^{\text {n }}$ no século XVI.

Neste texto, começo com o questionamento pertinente feito por Amartya Sen, economista de Bangladesh, Nobel de Economia em 1998, professor de economia e filosofia da Universidade de Harvard, no Reino Unido, e Calcutá, na Índia. Em seu livro A ideia de justiça (2009), ele questiona as teorias de justiça que chama de transcendentais para defender uma compreensão de justiça que diga respeito não a abstrações teóricas - ainda que racionais e coerentes - mas à vida das pessoas, aquela que elas efetivamente experimentam, sofrem e constroem com suor e sangue, diria eu. É essa ideia de justiça que nos cabe assumir como ponto de comparação (analogia empírica?) para entender a justiça de Deus e sua graça de acordo com o evangelho de Jesus. Não por acaso, o evangelista Mateus no sermão do monte se refere à ideia da justiça proclamada por Jesus como central para compreendermos o alcance da mensagem do reino ou reinado de Deus: "buscai, pois, em primeiro lugar, o seu reino e a sua justiça, e todas estas cousas vos serão acrescentadas" (Mateus 6.33). Quais são as necessidades a que Jesus se refere? Justamente tudo aquilo que é necessário para uma vida humana digna e justa: comida, bebida, vestimenta, sentido da vida, e tudo o mais que nós mesmos podemos acrescentar sem ferir o sentido do evangelho. ${ }^{7}$

4 WESTHELLE, Vítor. O Deus escandaloso. O uso e abuso da cruz. São Leopoldo: Sinodal; EST, 2008. p. 59.

5 WESTHELLE, 2008, p. 59.

6 WESTHELLE, 2008, p. 61.

7 No seu primeiro encontro com representantes dos movimentos sociais do mundo, em 28/10/2014, em Roma, o papa Francisco resumiu essas necessidades básicas com três palavras: terra, teto e trabalho. Pode ser um 
Na sequência, retomo o sentido paradoxal da teologia da cruz como formulado por Lutero e seguindo a releitura de Westhelle, para quem a cruz é o critério e a crítica de qualquer sistema idolátrico, seja na igreja ou na sociedade. Diante de sistemas racionais dominantes fundados na injustiça e na desigualdade, cabe reafirmar a distinção, mas ao mesmo tempo, a relação intrínseca entre fé e razão (ou racionalidade). Porém, nesse caso, em sentido crítico, tomando como ponto de partida irremediável a $c r u z$, tanto em seu conteúdo histórico como a cruz imperial da condenação de um inocente, quanto no sentido simbólico de sofrimento e morte "como termos intercambiáveis [... que assinalam] o ponto onde o significado semântico convencional de um

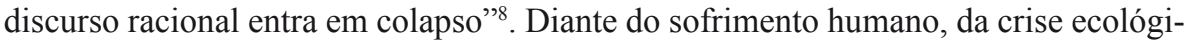
ca global, do desmoronamento do mundo político em curso, das incertezas que pairam sobre as pessoas, os povos e o futuro da humanidade, proclamar a solidariedade e a misericórdia como alternativas concretas e viáveis para a continuidade da vida neste planeta parece ser uma utopia. No entanto, essa mensagem pode ser uma das poucas razões hoje e no futuro para que tenhamos esperança. Como escreveu Westhelle, "o desafio para nós é sermos capazes de discernir, como Lutero fez [no século XVI], os lugares e tempos em que o quebrantamento, a vida ferida, as profundas crises estão recebendo uma operação plástica por parte dos sumos sacerdotes do novo evangelho global", que o teólogo canadense Douglas John Hall chamou de culto do "otimismo oficial". Todos os dias - compreensivelmente, se pode conceder - escutamos vozes públicas na imprensa televisiva, nas redes sociais e em conversas amistosas de que "isto vai passar" e logo mais - de preferência com uma ou mais vacinas eficazes e disponíveis para todas as pessoas - "poderemos retomar a nossa vida normal". Alguns mais cautelosos afirmam que vamos voltar ao normal possível. Ora, não seria esse discurso uma forma de "otimismo oficial" que não encontra razoabilidade em nenhum exame mais crítico da sociedade contemporânea? Eis aqui um tema, portanto, que nos questiona em profundidade e diz respeito ao centro da fé e da teologia cristãs.

\section{A ideia de justiça - no passado e no presente}

Amartya Sen, ao escrever $A$ ideia de justiça, inicia o livro afirmando seu ponto de partido prático e concreto: "O que nos move, com muita sensatez, não é a compreensão de que o mundo é privado de uma justiça completa - coisa que poucos de

patamar mínimo, mas para esses movimentos essas palavras reforçaram sua luta pelos direitos fundamentais da pessoa humana e do próprio meio ambiente. Fonte: $<$ https://agenciabrasil.ebc.com.br/geral/noticia/2014-10/ papa-francisco-recebe-lideres-de-movimentos-sociais-em-roma>. Acesso em: 30 out. 2020.

8 WESTHELle, 2008, p. 61. Cf. ainda RIEGER, Joerg. Cristo e o império. De Paulo aos tempos póscoloniais. São Paulo: Paulus, 2009, em que o autor vai em busca das várias formas de resistir aos diferentes impérios que visam dominar a humanidade, especialmente diante das teologias imperiais que tentam cooptar o Cristo da cruz para transformá-lo no Cristo do império ou da igreja. Sua hipótese procura mostrar o seguinte: "Há esperança de que Cristo mais uma vez afirme uma realidade diferente que não pode ser contida pelos poderes estabelecidos” (p. IX, Prefácio). Essa é também a tese de Vítor Westhelle, se eu bem o entendo.

9 WESTHELLE, 2008, p. 72. 
nós esperamos -, mas a de que a nossa volta existem injustiças claramente remediáveis que queremos eliminar"10. Esse é o caso não só na Índia, Paquistão ou Palestina, mas também em boa parte da África e aqui nas Américas Central, do Sul e do Norte, mesmo nos EUA, algo que a crise da pandemia da Covid-19 revelou aos olhos do mundo. E a injustiça como base da vida social não é apenas uma questão jurídica, mas abrange a economia, a política, a dinâmica cultural, a questão ambiental e, sobretudo, a vida de milhões de pessoas que crescentemente passam fome e vivem sem as mínimas condições humanas de existência. Por isso mesmo é uma questão teológica da mais alta relevância.

Ao defender a necessidade de uma teoria da justiça contemporânea e crítica, Sen adverte que é imperioso considerar três questões previamente: 1) é preciso incluir no arrazoado os modos de julgar como reduzir a injustiça e promover a justiça; 2) podem existir muitas razões distintas de justiça, cada qual sobrevivendo a um exame crítico, mas que resultam em conclusões divergentes, o que remete à pluralidade valorativa dependendo dos contextos em que cada qual se situa; 3 ) uma injustiça pode estar conectada à transgressão de comportamento e não a defeitos institucionais, mas a justiça está fundamentalmente conectada ao modo como as pessoas vivem e não meramente à natureza das instituições que organizam a sua vida social. ${ }^{11}$

Considero importante que o autor destaque na sua pesquisa essa dimensão da pluralidade de valores e de compreensões sobre um tema tão central, mas complexo. De qualquer forma, porém, o que me convence na sua abordagem é que ele não se deixa enredar por um discurso institucional que ele chama de justiça transcendental. Sua crítica refere, entre outros, os estudos teóricos do filósofo estadunidense John Rawls que escreveu o clássico A teoria da justiça (1971), em que defende a tese da "justiça como equidade" e "princípios de justiça" que dizem respeito exclusivamente a "instituições justas" como estrutura básica da sociedade, o que requer que as pessoas nessa sociedade cumpram integralmente as exigências do funcionamento apropriado dessas instituições. Ora, um simples exame dessa premissa pode demonstrar que tal sociedade não existe e que, portanto, a visão de justiça que se concentra nas instituições é inadequada. Por essa razão, Sen opta por outro caminho teórico e metodológico: seu ponto de partida para uma teoria da justiça que seja relevante e prática deve começar "da vida que as pessoas são capazes de levar. O foco sobre a vida real na avaliação da justiça tem muitas implicações de longo alcance para a natureza e o alcance da ideia de justiça" ${ }^{\prime 2}$.

Partir da vida real que as pessoas experimentam, sofrem, constroem pode ser mais complexo e controvertido, mas faz jus ao drama de pessoas de carne e osso que demandam justiça num mundo marcado por injustiças, humilhações e sofrimentos sem conta. E no qual as instituições não são perfeitas nem equânimes. Para Sen, os argumentos que elabora em seu volumoso livro transcendem a esfera do direito (civil ou não) e adentram as esferas da economia, da política e, a meu ver, também hoje os direitos

\footnotetext{
${ }^{10}$ SEN, Amartya. A ideia de justiça. São Paulo: Cia. das Letras, 2011. p. 9.

11 SEN, 2009, p. 11-13.

12 SEN, 2009, p. 13 (destaques no texto são de minha responsabilidade, RZ).
} 
étnicos, ambientais e culturais. Esse debate é tão importante porque sua percepção, conclusões e decisões terão certamente pertinência para programas e políticas práticas, no caso brasileiro, sobre políticas públicas nos mais diversos âmbitos da vida social, como na educação, na saúde, nos direitos trabalhistas, ambientais, territoriais (penso em povos indígenas, quilombolas, ribeirinhos e comunidades tradicionais) e culturais.

$\mathrm{O}$ autor esclarece, no entanto, que sua opção não descarta a importância das instituições, pois ainda que seu ponto de partida seja a vida e a liberdade das pessoas envolvidas nas questões de justiça e injustiça, "as instituições não podem deixar de ter um papel instrumental importante na busca da justiça". E isso é assim justamente porque "uma escolha apropriada das instituições tem um papel criticamente importante na tarefa de melhorar a justiça"'13.

Qual o problema então que ele procura resolver com essa sua abordagem? A busca da justiça numa dada sociedade concreta precisa considerar o exame minucioso de valores e prioridades a serem levadas em conta num debate público sobre os temas em discussão. Por exemplo, quando se decide uma grande obra pública - digamos uma hidrelétrica - em terras indígenas, a legislação atual prevê um amplo debate com as comunidades envolvidas, o pleno direito à informação, no caso especialmente os possíveis danos à vida comunitária e ao meio ambiente. Se isso não for contemplado, juridicamente, e a comunidade decidir que a obra é nociva à sua vida social, o projeto - por mais relevante que seja do ponto de visa governamental ou econômico - deveria ser suspenso e até proibido. Ora, é o que não vem acontecendo sistematicamente na Amazônia como se viu nos grandes projetos hidrelétricos desde os anos de 1970 até o presente. ${ }^{14}$

Ao contrário da visão de uma justiça transcendental que imagina a realização de uma justiça perfeita, normativa, imparcial, historicamente oriunda das sociedades ocidentais colonizadoras, o autor faz uso de outras referências, sobretudo de sociedades não ocidentais, em especial da Índia, e isso porque a filosofia política ocidental, a seu ver e em relação especialmente às exigências da justiça, tem sido por demais paroquial, isto é, reducionista ao ignorar outras possibilidades do seu exercício e prática.

Ele traz um exemplo bastante plástico e que se refere a dois conceitos de justiça provindos do antigo direito indiano e que são expressos pelas palavras em sânscrito niti e nyaya.${ }^{15} \mathrm{Niti}$ significa justiça e diz respeito tanto ao aspecto organizacional quanto à correção dos comportamentos. Já nyaya remonta ao que entendo como a prática da justiça, isto é, ao que resulta e ao modo como ela emerge na vida que as pessoas são mesmo capazes de levar ou praticar. Esses conceitos antigos nos ajudam a perceber que há dois tipos bastante diferentes - embora relacionados - de justiça que devem ser satisfeitos ou estar presentes na ideia de justiça. Mas, ao mesmo tempo, Sen explica que nesse intuito cabe não esquecer algo fundamental. Ao optar-se por uma

${ }^{13}$ SEN, 2009, p. 14. O exemplo do SUS acima colocado demonstra tal relevância.

${ }^{14}$ Para uma análise crítica desses projetos, entre muitos outros, cf. BRUM, Eliane. Brasil-país construtor de ruínas. Um olhar sobre o Brasil, de Lula a Bolsonaro. Porto Alegre: Arquipélago, 2019. p. 60-78. PINTO, Lúcio Flávio. Amazônia: o anteato da destruição. Belém: Grafisa, 1977. PINTO, Lúcio Flávio. Amazônia: no rastro do saque. São Paulo: Hucitec, 1980.

${ }^{15}$ SEN, 2009, p. 17. Também para o que segue. 
visão mais institucional ou organizacional na questão da justiça, vai-se buscar preferencialmente os "arranjos sociais perfeitamente justos", as "instituições justas" como a tarefa mais importante da teoria da justiça. Sen situa historicamente essa abordagem junto às teorias do "contrato social" (J. Locke, J-J Rousseau, I. Kant), que nos anos de 1950 influenciaram em especial a teoria de J. Rawls. Noutra visão, mais vinculada à vida prática ou à dinâmica social, presente em teóricos como A. Smith, Condorcet, M. Wollstonecraft, J. Bentham, K. Marx, J. Stuart Mill, a abordagem parte da vida que as pessoas levam, evidentemente influenciadas pelas instituições, mas também por seus comportamentos reais, as interações sociais e outras determinantes significativas. $\mathrm{O}$ autor se define por essa visão que ele chama de alternativa e comparativa, e que se junta à teoria da escolha social (Kenneth Arrow), que permite avaliar comparativamente as escolhas das pessoas, grupos, sociedades. Há, portanto, no seu debate o confronto de duas tradições: a contratualista e a comparativa. Na busca por uma justiça que encontre um fundamento tanto racional como prático e vinculado à vida, o autor sustenta que não existe um conflito irremediável entre razão e emoção, que é preciso considerar essas últimas em qualquer esforço teórico ou de percepção. E isso porque do ponto de vista crítico há muitos motivos para apontar o predomínio da desrazão no mundo e o irrealismo de quem afirma que o mundo seguirá inexoravelmente sua marcha para o progresso de forma racional. ${ }^{16}$

Em resumo, sua ideia de justiça - ainda que não descarte - vai além da abordagem do institucionalismo transcendental, cujas características se vinculam a uma ideia de justiça perfeita, e não nas comparações relativas entre justiça e injustiça. Também se concentra em trabalhar com as instituições, sem focalizar as sociedades reais, os comportamentos das pessoas e suas interações sociais. Sen, então, adota a abordagem comparativa que procura observar e partir das realizações sociais, daí a importância que dá a comparações entre sociedades diversas e suas formas de como é possível remover ou superar as injustiças evidentes nas relações sociais. Sua pergunta primeira, então, é: “como a justiça seria promovida?”, em lugar da pergunta que se refere à abordagem transcendental: "o que seriam instituições perfeitamente justas?"17. O foco são as realizações, a prática, e não as instituições e suas regras. Essa sua ideia de justiça exige - como ele deduz - uma mudança radical na formulação da teoria da justiça. Esse é o propósito de seu livro.

Isso basta para o que pretendemos discutir adiante para relacionar justiça humana com a justiça de Deus. Um exemplo da prática de Jesus pode nos servir de pequena luz aqui. Trata-se da questão de como guardar o sábado, segundo a lei de

${ }^{16}$ HINKELAMMERT, Franz J. Cultura de la esperanza y sociedad sin exclusión. San José, Costa Rica: DEI, 1995. Nesse livro, Hinkelammert apresenta argumentos para a irracionalidade do racionalizado no sistema capitalista, levanta a necessidade do aprendizado sobre os critérios de vida e morte e relaciona a racionalidade da loucura sistêmica com a loucura de sua racionalidade (p. 300ss). Na discussão sobre possíveis soluções para o impasse global a que estamos sujeitos, sua tese libertadora afirma que não é possível superar a irracionalidade do racionalizado a não ser mediante uma ação solidária que dissolva as forças compulsivas dos fatos que nos dominam, isto é, do sistema global das mercadorias (p. 321ss), que o papa Francisco caracteriza como economia para a morte.

17 SEN, 2009, p. 39. 
Moisés. Mateus 12.1-8 narra um fato emblemático. Era um dia de sábado. Jesus e seus discípulos passavam pelos campos e - diz o texto -, estando com fome, entraram na seara, colheram algumas espigas e comeram. Os fariseus, mestres da lei, reagiram dizendo: Eis que os teus discípulos fazem o que não é lícito fazer em dia de sábado. Jesus, porém, lhes respondeu: Não lestes o que fez Davi quando ele e seus companheiros tiveram fome? Como entrou na casa de Deus, e comeram os pães da propiciação, os quais não lhes era lícito comer, nem a ele nem aos que com ele estavam, mas exclusivamente aos sacerdotes? Ou não lestes na lei que, aos sábados, os sacerdotes nos templos violam o sábado e ficam sem culpa? Pois eu vos digo: Aqui está quem é maior que o templo. Mas se vós soubésseis o que significa: 'Misericórdia quero, e não holocaustos', não teríeis condenado a inocentes.

O exemplo de Jesus é certeiro, pois questiona uma interpretação fechada e transcendental da lei. Talvez até se pudesse dizer idealista. Jesus coloca em tela de juízo algo concreto e vivencial: a fome das pessoas. O direito de comer para acabar com a fome pode não estar escrito num código formal, mas é o que a vida clama e essa deve vir em primeiro lugar. Quando se discute sobre o que seria justo ou injusto num determinado lugar ou tempo, há que partir da vida como ela é, ou para ficar com o critério adotado por Sen: "a vida que as pessoas são realmente capazes de levar"18.

\section{Ironia, cruz e teologia paradoxal - a propósito da teologia da cruz de Lutero e da justiça de Deus}

Westhelle é mestre no manejo dos conceitos em diversas línguas. Mas no caso da teologia de Lutero, que ele estudou diligentemente por décadas, alguns desses conceitos e expressões ressaltam em seus textos. No tema deste artigo, um desses conceitos diz respeito às máscaras de Deus (larvae dei), que vem da teologia escolástica, mas que Lutero reinterpretou bem ao seu modo na polêmica com aquela teologia. ${ }^{19}$

Superando o dualismo platônico entre as esferas espiritual e material, ao trabalhar com o que ficou conhecido como "dois reinos", categorias que serviram para diferenciar os regimes eclesiástico e secular, Lutero - como demonstrou o estudo do teólogo sueco Gustav Törnvall - rompeu com a interpretação escolástica e propôs uma interpretação funcional, por meio da qual pode afirmar que tais regimes são expressões

${ }^{18}$ Quando, em 1518, Lutero aceitou debater suas ideias no que ficou conhecido como Debate de Heidelberg, ele apresentou várias teses para discussão. Uma delas já na época levantava precisamente este tipo de abordagem, em contraste com os teólogos escolásticos que ele chama de teólogos da glória: "O teólogo da glória afirma ser bom o que é mau, e mau o que é bom; o teólogo da cruz diz as coisas como elas são" (Tese 21). Na explicação, ele afirma ainda: "Já dissemos, no entanto, que Deus não é encontrado senão nos sofrimentos e na cruz". Adiante, Lutero reconhece a importância da sabedoria humana: "Não obstante, aquela sabedoria não é má, nem se deve fugir da lei; sem a teologia da cruz, porém, o ser humano faz péssimo uso daquilo que há de melhor" (Tese 24). LUTERO, Martinho. Obras selecionadas. São Leopoldo: Sinodal; Porto Alegre: Concórdia, 1987. v. 1, p. 50s.

${ }^{19}$ Sobre a questão das máscaras de Deus na vida dos povos indígenas e na pastoral de convivência, cf. documentos do COMIN - Conselho de Missão entre e com Povos Indígenas reunidos no Cadernos do COMIN, $\mathrm{n}^{\circ}$ 1, São Leopoldo, 1982. Significativamente o título do Caderno é: A máscara índia de Deus. 
do âmbito da teologia da criação que dizem respeito à autorrevelação de Deus, mas de modo indireto, não evidente por si, portanto, através de máscaras, que para ele se apresentam como "a palavra invisível de Deus (verbum dei) e o mundo visível". Disso resulta que ambos os "reinos" são manifestações ou aspectos funcionais da revelação de Deus, e que Lutero com muita sabedoria caracteriza como "um reino do ouvir (Hörreich) e um reino do ver (Sehereich)" ${ }^{20}$. Como bem explicou Walter Altmann, em seu Lutero e a Libertação, o reformador afirma que Deus atua em "ambos os reinos", apenas de modos diferentes e segundo lógicas próprias do ver e do ouvir, seguindo aqui Westhelle ${ }^{21}$. E mesmo assim, em ambos, o que define a ação de Deus só é acessível por meio da fé, pois ninguém tem acesso a Deus senão por meio da fé, que por sua vez é sua dádiva no Espírito, como o são também o mundo criado e sua Palavra.

Westhelle explica que, para Lutero, a distinção básica se dá entre o que é visível e a Palavra, entre a criatura e o Criador, entre o exterior e o interior, em suma, entre o que os sentidos percebem e a razão infere ou intui, e aquilo que a graça divina revela. É essa forma de compreender a revelação que Westhelle chama de "relação paradoxal", na medida "em que um (o visível) aponta para o outro (a Palavra), mas isso de maneira simultaneamente negada ou dissimulada". É por essa razão que Lutero, mesmo sendo um mordaz crítico da filosofia escolástica e ao conceito da analogia (Tomás de Aquino), não a suprime, mas inclui em sua forma de argumentar elementos e percepções que questionam a correspondência analógica.

Assim, para bem entendermos algumas das formulações paradoxais da teologia bíblica e do próprio Lutero, é necessário, até imprescindível, saber relacionar o audível e visível com a relação necessária - mas também ambígua - da Palavra ou do evangelho com as máscaras ou as manifestações do mundo visível, e vice-versa, como afirma Westhelle. É a esta relação - que eu diria tensa entre o invisível e o visível na teologia de Lutero - que Westhelle caracteriza como a "ironia irrompendo no âmbito da analogia. O que a máscara revela é a própria Palavra oculta em suas rachaduras"22.

Essa maneira de elaborar ironicamente a teologia, própria de Lutero, faz com que ele, sem abrir mão da razão na vivência de fé (a fé, portanto, não é cega, mas é sim amolada!), a pressiona de tal forma que a leva até seus limites, e como o completa Westhelle, "até as margens de sua validade", até o ponto em que ela não funciona mais e tem que ser abandonada em troca daquilo que ele chama fé ou fidúcia, a confiança na palavra de Deus ou seu evangelho e que provém de forma inesperada, sem brilho ou poder visível, da periferia, da pobreza, da fraqueza e do sem sentido de uma cruz a que são condenadas as pessoas tidas como subversivas, que põem em perigo a esta-

${ }^{20}$ WESTHELLE, 2008, p. 57. Também para o que segue.

${ }^{21}$ ALTMANN, Walter. Lutero e a libertação. 2. ed. revista e ampliada. São Leopoldo: Sinodal, EST, 2016. Sobre a questão das máscaras de Deus e sua relação com a relação tensa mas criativa e crítica entre ambas na teologia da Lutero, cf. HANSEN, Guillermo. Las suturas de la razón y el cortocircuito de la fe: Lutero a la luz de las filosofías cognitivas contemporáneas y la teoría evolutiva. In: WESTHELLE, Vítor; ZWETSCH, Roberto E. (Eds.). Fides et ratio. Temas de teologia e filosofia suscitados por Lutero e a Reforma do século XVI. São Leopoldo: Sinodal; EST; ASTE, 2017. p. 252-269.

22 WESTHELLE, 2008, p. 58. 
bilidade do império e suas razões. É nesse sentido que se pode falar de uma teologia da cruz, que emerge de um lugar desacreditado e impróprio para a manifestação de um Deus glorioso, onipotente, que se espelha naqueles que detêm poder, força e fama.

$\mathrm{Na}$ avaliação da teologia da cruz, Westhelle tece considerações sobre a economia da salvação como Lutero a recebeu dos teólogos medievais, especialmente Anselmo e Abelardo. Ao relembrar o drama existencial do reformador com sua pergunta-chave: como alcançar um Deus misericordioso? Westhelle retoma a antiga questão de como justificar o mal no mundo, ou seja, a pergunta pela justiça de Deus. As respostas que Lutero encontrou para seu drama não o satisfizeram, pelo contrário, o deixaram ainda mais angustiado. Pois na velha maneira de responder, como em Anselmo, a justiça de Deus precisa ser satisfeita, pois ele não aceita o pecado e este deve ser condenado de todas as formas. Ocorre que Anselmo se baseou num princípio jurídico para formular sua resposta: a cada qual o que é seu (suum cuique), de modo que na nossa relação com Deus, como pecadores, temos uma dívida a ser paga, do contrário, só nos restaria a punição, a condenação eterna. Mas como pagar se não temos o que oferecer? Aí entra a obra de Cristo e seu sacrifício por nós. Cristo pagou a dívida e nós assim fomos resgatados para viver de acordo com os mandamentos de Deus. A dívida foi cancelada. Para Abelardo, a resposta não se encontrava no sistema jurídico, mas antes no amor de Deus que evade a questão da justiça e nos atinge até mesmo em nossa morte, de modo que livres do pecado possamos amar como Jesus amou e nos tornar herdeiros de seu reino.

Tais respostas não convenceram o atribulado monge Lutero. Ele pressentia que algo nelas falhava, quer dizer, não explicitava claramente qual era mesmo a obra de Cristo em nosso favor. Para Lutero, a questão não respondida dizia respeito ao entendimento da justiça de Deus. Nessa busca ele encontrou os cantos do servo sofredor de Isaías e particularmente Isaías $53 .{ }^{23}$ Lutero encontra a justiça de Deus em Cristo e em seu evangelho. Supera assim uma justiça formal e transcendental, por uma ação concreta de Deus em Cristo, que se torna assim nossa justiça. Não por acaso ele tira a conclusão de sua interpretação bastante ousada, segundo a qual a justiça de Deus nem pode ser saldada com um sacrifício nem pode ser menosprezada por uma compreensão deficiente de seu amor incondicional. A justiça de Deus é de outra natureza, ela diz res-

23 LUTERO, Martinho. Preleção sobre Isaías 53 (1527-1530). In: Obras selecionadas. São Leopoldo: Sinodal; Porto Alegre: Concórdia; Canoas: Ulbra, 2017. v. 13, p. 278-293. p. 290s. Nesse comentário, Lutero encontra uma resposta convincente. “Justificará a muitos com seu conhecimento, porque carregará sobre si as suas iniquidades' (v. 11). Aqueles que confessam que seus pecados foram levados por ele são justos. É uma extraordinária definição de justiça. Os sofistas (para Lutero, os teólogos escolásticos de modo geral) dizem que a justiça é a vontade inabalável de dar a cada qual o que é seu. Aqui ele diz que a justiça é o conhecimento de que Cristo carrega nossas iniquidades". E adiante, completa: "esse conhecimento [de Cristo] é a justiça formal e substancial dos cristãos, isto é, a fé em Cristo, da qual me apodero mediante a palavra. É verdade que me apodero da Palavra por meio do intelecto, mas concordar com essa palavra é obra do Espírito Santo, não da razão, a qual sempre procura suas próprias formas de justiça. Mas a Palavra propõe outra justiça por meio da meditação e das promessas da Escritura, que fazem com que essa fé seja considerada justiça. A nossa glória é saber ao certo que nossa justiça é divina na medida em que Deus não leva em conta nossos pecados. Logo, nossa justiça nada mais é do que a consideração de Deus". (grifo nosso). 
peito à "consideração de Deus". Assim, conhecer a Cristo é conhecer a justiça de Deus. E responde ao desafio de se apropriar dela, o que na realidade do mundo significa rever conceitos e escolhas, modos de ser, ver, ouvir e caminhar. Westhelle assim explica essa concepção libertadora. Conhecer a Cristo como nossa justiça é saber que - se ele veio para estar em nosso lugar na relação com Deus, isso também significa que temos a liberdade e o convite de nos colocar no lugar do próprio Cristo. "É isso que Lutero queria dizer com a expressão, muitas vezes citada, de que os fiéis são 'Cristos"'24.

Para Westhelle, a redescoberta da teologia da cruz por Lutero representou sua tentativa ousada de libertar a teologia do cativeiro dos modos dominantes de pensar na época. Era necessário questionar a racionalidade da meritocracia na relação com Deus. Foi isso que fez Lutero investir ainda bem jovem (1517) contra as indulgências que a igreja oferecia como forma de pagar pecados e assim libertar as pessoas de suas muitas culpas, garantindo-lhes o crédito necessário para ascender ao céu, ao reino da glória e da presença de Deus. Esse esquema creditício e de pagamentos de dívidas espirituais não por acaso se firmou quando o capitalismo dava seus primeiros passos com o surgimento das casas bancárias e os modos de instituir a moeda circulante como medida de todas as coisas, mercadorias, relações e, por fim, até mesmo para avaliar o ser humano, seus direitos e deveres, e ainda segundo o modo de pensar na época, direitos e deveres espirituais, mas também materiais junto a senhores, nobres e a própria igreja. ${ }^{25}$

Esse sistema meritocrático foi abalado em sua empáfia pela pregação e a teologia da Reforma - Lutero e outros reformadores - a tal ponto que pôs em tela de juízo esses modos de pensar e conduzir a vida social, política e econômica, mas também espiritual, proclamando revolucionariamente que o que salva é a justiça de Deus e não qualquer forma de justiça humana. Essa é necessária e útil, mas diante de Deus nada dessa contabilidade vale. Diante de Deus temos apenas Cristo, sua cruz e a fraqueza de Deus. É dessa fraqueza que temos de nos valer para bem nos relacionarmos com o Deus vivo. Ninguém é suficientemente bom, justo e verdadeiro para apresentar-se diante de Deus. Pelo contrário, o que nos salva é Deus mesmo e sua graça libertadora, que se achegou a nós de forma silenciosa, da forma mais fraca como numa criança envolta em fraldas, nascido de uma jovem mulher camponesa num lugar totalmente suspeito, a estrebaria de um rincão esquecido do poderoso Império Romano. E nessa trajetória humana, Cristo termina na cruz do império, condenado injustamente, torturado e assassinado como um ladrão, entre dois malfeitores.

A cruz é a inescapável manifestação escandalosa de um Deus que não julgou sua divindade como algo que o excluísse da frágil e pecadora humanidade. Antes ela foi o atestado de um Deus que se esvaziou de sua divindade para solidarizar-se radicalmente com a miséria humana e desde aí, assumindo a escravidão, o desprezo e a

24 WESTHELLE, 2008, p. 53.

${ }^{25}$ O teólogo luterano Ricardo Rieth é especialista nas questões da economia do tempo de Lutero. Sua tese de doutorado versa sobre a ganância na teologia da Lutero. Cf. RIETH, Ricardo. Lutero e o conhecimento sobre Deus e o ser humano: a relação de fé e razão nos âmbitos da economia e da educação, em que resume seus principais argumentos. In: WESTHELLE; ZWETSCH, 2017, p. 141-158. 
desumanidade que caracteriza a vida humana, entregar-se plenamente ao sentido de sua vida como filho de Deus ou servo de Deus (Fp 2.5-11). Por isso a mensagem de sua ressurreição é tão profundamente nova uma vez que está vinculada não à vitória de um herói, mas antes à derrota de um ser humano que - nas palavras de um soldado que o vigiava na cruz - era "verdadeiramente um homem justo" (Lucas 23.47) ${ }^{26}$. Só temos condições de viver e praticar sua ressurreição se nos arriscarmos como as mulheres seguidoras de Jesus a acompanhá-lo até aos pés da cruz e aprender dela e das muitas cruzes que violam a vida de tanta gente neste mundo. ${ }^{27}$

Diante disso, temos um caminho aberto para seguir, ainda que exigente e rigoroso. Não andamos pelo que vemos, mas por aquilo que amamos, escreveu um teólogo metodista argentino. Entendo ainda que andamos não por certezas, mas no difícil caminho da fé, que não se baseia em certezas duvidosas (Hb 11.1), mas na revelação de um Deus que se esvaziou e nos confronta com o lado inverso da história, como escreveu Gustavo Gutiérrez, o lado dos de baixo, do outro lado da linha abissal, como escreveu o sociólogo português Boaventura Sousa Santos. ${ }^{28}$

A “obra estranha de Deus" (opus alienum), como explica Westhelle a partir de artigo de Timothy Wengert, não é uma afirmação prescritiva, mas antes descritiva, assim revela nossa condição e nossa experiência dela. E isso é importante porque nos livra de fazermos especulações sobre Deus e sua obra. Olhando para a cruz, parece que Deus nos abandonou. Escreve então Westhelle: “Quem reconhecer isso não está mais resistindo à graça de Deus". Mas tal constatação não nos impede de lamentar e clamar contra a cruz, o mal e a impiedade. E Deus não nos impede tal atitude. Como Westhelle então lembra, na linguagem forjada na América Latina, a opção pelos pobres, excluídos e pessoas que sofrem doenças devastadoras, parece ser mesmo "uma

${ }^{26}$ O processo fraudulento que se realizou sobre Jesus de Nazaré pelas autoridades judaicas e do Império Romano até hoje suscita estudos e tentativas de interpretação. Mas a boa ciência jurídica, com base nos textos evangélicos que são testemunho e não se preocuparam em tecer argumentos jurídicos, tem há muito percebido que a condenação de Jesus foi uma fraude a serviço da ordem dominante. Cf. AGAMBEN, Giorgio. Pilatos e Jesus. Florianópolis: UFSC; São Paulo: Boitempo, 2013.

27 WESTHELLE, 2008, p. 117-132. O autor traz aqui sua reinterpretação da ressurreição, capítulo em que sustenta que a mensagem da ressurreição é a abertura para o direito à insurgência (trata-se de praticar ressurreição, ele escreve). Retomando Lutero, ele procura mostrar que a teologia da cruz é um apelo para "uma prática da paixão (usus passionis), uma experiência envolvente e uma disposição intencional” de agir, ainda que de modo escandaloso para o próprio Deus (p. 119s). Na cruz e no sofrimento de um inocente, Deus se revela, mas de modo "elusivo", indireto, de maneira oculta, como o expressou Karl Barth. Segundo Barth, "o nervo do pensamento de Lutero é que a larva Dei (máscara de Deus), o caráter indireto de sua autocomunicação, é duplo, sendo emitido não somente através de seu caráter criado, mas também através da pecaminosidade da criatura" (p. 121). Sobre a centralidade da fidelidade e ousadia das mulheres no seguimento de Jesus, a teologia feminista vem demonstrando à exaustão como a presença e participação das mulheres foi encoberta pela tradição patriarcal que dominou a igreja cristã já desde o final do primeiro século. Cf. SCHÜSSLER-FIORENZA, Elisabeth. Discipulado de iguais. Uma ekklesiologia feminista de libertação. Petrópolis: Vozes, 1995. Sobre o esquecimento da participação decisiva das mulheres no movimento da Reforma do século XVI, cf. BEISE ULRICH, Claudete. A atuação e a participação das mulheres na reforma protestante do século XVI. Estudos de Religião, v. 30, n. 2, p. 71-94, maio/ago. 2016.

28 SANTOS, Boaventura Sousa. O fim do império cognitivo. A afirmação das epistemologias do Sul. Belo Horizonte: Autêntica, 2019. 
redundância na medida em que essas são as pessoas que por se saberem como tais, e na medida em que o fazem, estão dispostas a se fiar na graça de Deus que as erguerá, como Deus fez com aquela humilde moça solteira e grávida na Galileia"29. É nesse sentido, então, que, para Westhelle, a cruz se torna critério e crítica a todo e qualquer sistema idolátrico ou totalitário. Lutero, ao elaborar sua teologia da cruz, não pensava de modo abstrato ou escolástico. Ele conhecia o sofrimento humano que vigorava em seu país e no meio de sua gente. Ao elaborar pungentes sermões sobre a usura, Lutero tinha plena consciência das práticas iníquas que o capitalismo financista emergente impunha às pessoas, aos comerciantes e mesmo aos governantes. Não por acaso, lembra Westhelle, Karl Marx chegou a chamar o reformador de "primeiro economista alemão"30. Não é, pois, um despropósito assegurar também hoje que a teologia fiel ao Crucificado só pode ser uma teologia da cruz solidária com os crucificados de todos os tempos e lugares.

Como escrevi na apresentação do livro de Westhelle, a cruz é a crise do cristianismo, das igrejas cristãs e de suas teologias. ${ }^{31}$ Ela não permite que façamos vistas grossas à injustiça, às iniquidades e violências cotidianas impostas às massas empobrecidas diariamente. Pior, desgraçadamente e com frequência, o discurso da racionalidade desse sistema global o faz em nome do que é justo, do que é melhor para "a sociedade" e, em certos casos, em nome de Deus! Idolatria em uso e abuso, se eu pudesse resumir arriscando a pele. Mas a cruz é o mais radical questionamento da fé cristã, da igreja de Jesus Cristo e das pessoas que nele creem. Passar ao largo dessa cruz e das pessoas crucificadas hoje, sublimá-la com discursos piedosos ou acadêmicos, fazer uso dela para sacrificar pessoas ou suas consciências, por vezes, atribuladas de muitas formas, é violentar a fé e a credibilidade das pessoas, sobretudo as mais vulneráveis e destituídas de uma visão crítica. Também é atestar quão incômoda é essa cruz implantada no chão do mundo e no coração da fé da igreja cristã. Teologia cristã que se quer fiel ao Crucificado e à fé apostólica se encontra diante de um desafio sem fim e por isso mesmo impostergável: elaborar o caminho e a caminhada que esse "escândalo" (1Co 1.18ss) causou no passado e continua causando no presente. Foi esse o propósito de Vítor Westhelle. Recordar esse desafio e assumi-lo em nosso momento histórico é nossa tarefa, de resto, sempre inconclusa e, por vezes, errática.

29 WESTHELLE, 2008, p. 68. O autor faz uma referência indireta ao cântico de Maria, no qual ela afirma de forma profética que Deus "derrubou de seus tronos os poderosos e exaltou os humildes" (Lc 1.52). Lutero escreveu um importante comentário sobre esse cântico, em que exalta Maria como profetiza e questionadora de todas as formas de poder político, sobretudo, das tiranias. E que bons governantes deveriam dar ouvidos à jovem da Galileia, se quisessem governar de forma justa. Para uma reflexão atual, cf. ZWETSCH, Roberto E. Lutero, justiça social e poder político. In: ZWETSCH, Roberto E. (Org.). Resgatando a radicalidade da Reforma. São Leopoldo: CEBI, 2019. p. 210-229. Nesse texto, escrevo que, para Lutero, o Deus de Jesus não nos ensina a olhar para cima, isto é, para os poderosos, mas antes para baixo, pois é ali, em meio à pobreza e aos empobrecidos, que ele se faz presente sub contraria specie. Novamente, temos aí a linguagem paradoxal do reformador.

${ }^{30}$ WESTHELLE, 2008, p. 71.

${ }^{31}$ Apud WESTHELLE, 2008, p. 6ss. 


\section{Sobre justiça, sofrimento humano e solidariedade libertadora}

Chegados até aqui, penso que se trata agora, ainda que de modo fragmentário, de perguntar pela relevância e atualidade da teologia da cruz e sua contribuição para a caminhada cristã neste século que se apresenta com todas as cores apocalípticas que se podem observar. Apocalipse entendido aqui tanto em termos escatológicos quando revelatórios, pois crises globais como a que vivemos se podem turvar e confundir nossa mente, ao mesmo tempo servem para revelar discursos obscenos, posturas e políticas genocidas. Ao menos, se considerarmos as grandes questões globais que desafiam o mundo e os governos neste início de século: a crise climática, o aumento extraordinário do abismo que separa irremediavelmente uma minoria cada vez mais rica no mundo diante de bilhões de seres humanos empobrecidos sistematicamente e milhões sujeitos à fome degradante e injusta. E para não ignorar, há que compreender e enfrentar com inteligência e o cuidado extremo que se faz necessário a pandemia da Covid-19, que assolou o mundo inteiro e impôs aos países e povos uma crise global econômica, política, cultural e espiritual diante da qual não se tem à vista uma resposta satisfatória. Aliás, possivelmente, haverá a necessidade de muitas respostas à pandemia e suas consequências, sem que as vacinas que vêm sendo pesquisadas e produzidas sejam por si só a solução para que tudo volte ao normal, como vozes levianas vêm proferindo nas redes sociais e televisivas. Evidentemente, todas as pessoas sensatas esperam e apoiam as pesquisas sobre vacinas, mas daí a proclamá-las como a salvação do mundo vai uma distância que nem os melhores cientistas seriam capazes de encurtar.

Diante do que estamos vivendo neste momento da história do planeta, não haverá normalidade possível, nem hoje nem no futuro imediato, ainda que se queira fazer crer em tal discurso através da propaganda do "otimismo oficial" das mídias e corporações. Estamos frente a uma inflexão histórica sistêmica, como jamais antes se mostrou de modo tão evidente, mas ao mesmo tempo tão obscuro e ambíguo. O filósofo esloveno Slavoj Zizek escreveu, em artigo recente, que, mesmo em meio à crise provocada pela pandemia, nossa vida social "não está paralisada por estarmos tendo que obedecer a regras de isolamento social e quarentena - em tais momentos de (ou do que pode parecer uma) paralisia as coisas estão mudando radicalmente. A rejeição ao lockdown é, na verdade, uma rejeição à mudança. Ignorar isso significa nada menos que um tipo de psicose coletiva. Escuto nas queixas contra o lockdown uma confirmação inesperada da afirmação de Jacques Lacan de que a normalidade é uma versão de psicose..$^{32} \mathrm{Ou}$ seja, o mundo e nossas vidas vão precisar apostar numa mudança radical, se quisermos imaginar algum futuro humano digno do nome.

A avaliação crítica de Zizek sobre como as pessoas se colocam na crise, a meu ver, levanta uma pergunta incômoda à teologia e à fé cristã: com que mensagem ou discurso procuramos responder à crise da pandemia? Palavras de otimismo piedoso ou

32 ZIZEK, Slavoj. Site Outras Palavras e Blog da Editora Boitempo. 22/07/2020. Disponível em: <https:// outraspalavras.net/outrasmidias/zizek-a-volta-ao-normal-e-a-psicose-suprema/>. Acesso em: 01 nov. 2020. 
declarações de culpa coletiva? Esperança realista ou ilusões espirituais bem intencionadas? Como não levar a sério o que ele chama de psicose coletiva? Como manter a mente e o espírito saudáveis e atentos sem cair no obscurantismo ou na euforia ilusória?

Não há respostas fáceis nem muito menos milagrosas. São tempos difíceis para todas as pessoas, seja o povo trabalhador que não pode ficar em casa, como quem trabalha nos serviços de saúde, de alimentação e transporte coletivo, sejam as forças de segurança e controle públicos, ou mesmo intelectuais que buscam compreender o que se passa e que possíveis saídas se apresentam. Mas também aquelas pessoas, grupos e comunidades que puderam tomar os cuidados recomendados pela OMS - Organização Mundial da Saúde, para todas essas pessoas "ficar em casa", sair apenas para resolver necessidades essenciais e que, por isso mesmo, colaboraram decisivamente para mitigar os casos de contágio e os números de mortes, o prolongado isolamento social, o confinamento em espaços reduzidos e todos os problemas que advêm dessa circunstância inédita e não escolhida ou esperada, foi de grande sofrimento. Isso sem esquecer as vítimas e o luto que atingiu milhares de famílias. Hoje sofro, nada mais, escreveu Cesar Vallejo.

De outra perspectiva, vêm chamando a atenção da imprensa, sobretudo das redes alternativas e comunitárias, as formas cada vez mais criativas com que populações urbanas de periferia ou movimentos camponeses de agricultura ecológica ou orgânica vêm enfrentando essas limitações, realizando ações solidárias de auto-organização e ajuda mútua. $\mathrm{E}$ isso vem acontecendo de forma importante também entre comunidades indígenas da Amazônia e outras regiões, especialmente diante da invasão de seus territórios por garimpeiros, grileiros de terra e madeireiros ilegais. Em algumas áreas, até mesmo o fechamento das fronteiras desses territórios a qualquer entrada externa vem sendo realizado como forma de manter a comunidade a salvo de contaminação. Face à completa descoordenação do governo federal na crise provocada pela pandemia, da sistemática atitude das autoridades de negar sua virulência, em especial por parte do presidente em exercício, é de admirar que na base da sociedade ainda encontremos coragem e capacidade para tal autoproteção.

Fico me perguntando se nesse caso não estaríamos diante daquela virtude que o apóstolo Paulo tanto recomendava e que pode ser uma das principais características de seu ministério: a parresía, que se pode traduzir por ousadia, teimosia, perseverança. Ao ler o livro de Vítor Westhelle, ponto de partida para esta reflexão, tentei compreender seu escrito como uma teologia transgressora, no sentido de uma teologia que transgride os limites das teorias conhecidas e aceitas costumeiramente, teorias que fazem o esforço para circunscrever racionalmente o "escândalo da cruz", ou, por outro viés, uma teologia que questiona os discursos que evitam as contradições da realidade, o que se apresenta ignóbil ou sem o brilho esperado, e que por isto tergiversam, transformando a palavra da cruz no seu oposto, descaracterizando o centro da fé cristã.

Por essa e outras razões é justo afirmar que a teologia crítica, transgressora, da cruz, só se pode pôr em prática mediante uma "ruptura epistemológica" que nos permite chegar - ainda que às apalpadelas, por vezes - às verdades ocultas não apenas por trás do madeiro, mas nele mesmo, na sua crueza e falta de sentido. Quando escutamos com ouvidos atentos e bem abertos o grito de Jesus na cruz: "Deus meu, por 
que me desamparaste?" (S1 22.1; Mt 27.46), estamos diante da questão crucial, que aparece no texto magistral do livro de Jó, e que Gustavo Gutiérrez trabalhou exaustivamente no seu livro Falar de Deus a partir do sofrimento do inocente ${ }^{33}$. Gutiérrez adianta que Jó enfrentou seus amigos que se solidarizaram com sua desgraça, mas vieram com um discurso que ele, em sã consciência, não podia aceitar nem crer. Ele se rebelou contra a injustiça sofrida e mesmo contra Deus, mesmo sem deixar de confiar nele e clamar por ele. E Deus o aceitou rejeitando os piedosos teólogos que queriam fazê-lo reconhecer seu erro, sua injustiça. Jó se colocou diante do mistério de Deus com toda coragem que ainda lhe restava, sem tergiversar, sem se esconder diante de uma falsa humildade ou de uma arrogância autossuficiente. Ele procurou ser honesto consigo e com Deus. E Deus o acolheu. Foi assim que Jó descobriu a gratuidade e o silêncio como atitudes fundamentais para acolher o mistério da graça de Deus.

Como Gutiérrez explica, o livro de Jó apresenta uma longa reflexão não sobre um fato histórico libertador, mas uma construção teológica literária de profunda repercussão na tradição da fé judaica. Trata-se de uma obra que faz parte da Sabedoria, mas que não ignora questões fundamentais da vida prática: a transcendência de Deus, o problema do mal, o sofrimento humano, a questão da retribuição, a amizade, entre outras. No centro do livro, emerge a questão da linguagem sobre Deus ou como falar de Deus e, no limite, como falar de Deus a partir do sofrimento do inocente. Para Gutiérrez, é o que lhe permite afirmar que Jó nos ajuda a falar de Deus a partir do sofrimento do povo oprimido, das pessoas vulneráveis, pobres, vilipendiadas em seus direitos básicos ${ }^{34}$, como vemos na América Latina e alhures.

Gutiérrez afirma que, sendo uma construção literária, não é possível deixar de perceber que sua autoria está marcada por alguém que padeceu em seu corpo e espírito, porque o livro apresenta o protesto e a lamentação de um personagem que fala de Deus a partir de uma experiência pessoal. Mas algo que ganha realce na interpretação de Gutiérrez é sua conclusão: ao fim e ao cabo, reclamando por sua inocência, Jó descobre mesmo a graça de Deus, o que paradoxalmente significou estabelecer uma relação profunda, mas aparentemente contraditória entre a dor e o sofrimento humano com a fé e a esperança. ${ }^{35}$ É que o que me fez chegar a relacionar esse livro com a teologia da cruz. Explicitamente, escreve Gutiérrez:

comunhão na dor e na esperança, no desamparo da solidão e na entrega confiante na morte e na vida, essa é a mensagem da cruz: "loucura para os que se perdem, mas poder de Deus para os que se salvam" (1 Cor 1,18), e portanto susceptível de passar despercebida para os que têm olhos para prodígios e expressões de poder. Essa força é, ao mesmo tempo e paradoxalmente, "fraqueza divina" (1 Cor 1,25). Ela anima a

33 GUTIÉRREZ, Gustavo. Falar de Deus a partir do sofrimento do inocente. Uma reflexão sobre o livro de Jó. Petrópolis: Vozes, 1987.

34 GUTIÉRREZ, 1987, p. 21.

35 GUTIÉRREZ, 1987, p. 45. 
linguagem da cruz - síntese do dizer profético e do dizer contemplativo - que constitui a única apropriada para falar do Deus de Jesus Cristo ${ }^{36}$.

É muito importante verificar a força espiritual desse escrito de um dos teólogos pioneiros da teologia da libertação. Ele afirma claramente que essa teologia da cruz ensina que só através do sofrimento e da solidariedade com quem sofre, como foi com Jesus, é possível falar de Deus. Deus se manifesta mesmo lá onde ele aparentemente está ausente, onde não podemos senti-lo ou vislumbrar seus sinais. Por isso é que Gutiérrez pode afirmar adiante: "O sofrimento humano, sejam quais forem suas causas - sociais, pessoais ou outras - é uma questão de suma importância para o discurso teológico"37. Não, porém, porque a fé cristã seria masoquista ou a linguagem dos derrotados, e sim porque ela encontrou na fé e na amizade de Jesus a palavra e a atitude firme e adequada para - mesmo no sofrimento - não se deixar abater, perseverando nele ainda que em meio ao sem sentido, apostando na ousadia de crer, de lamentar, de clamar, de gritar, de protestar e, finalmente, de teimar pela vida, seja na dor ou na alegria.

Por isso vale assumir uma das perguntas finais no estudo de Gutiérrez: como anunciar o amor de Deus em meio de tão profundo desprezo pela vida humana? Hoje podemos acrescentar, em meio ao descalabro da crise ambiental e da destruição de tantos biomas que colaboram de maneira fundamental para o equilíbrio do planeta? Sua conclusão nos continua a desafiar: "Só levando a sério a dor humana, o sofrimento do inocente e vivendo sob a luz pascal o mistério da cruz no meio dessa realidade, será possível evitar que nossa teologia seja um 'discurso vazio"'38. Somente dessa forma teremos condições de dar uma resposta ousada e desafiadora a quem procura - amaciando a dura realidade deste mundo - consolar de forma inoportuna e ilusória a quem sofre, muitas vezes, sem motivo e sem causa. Segundo Jó, "vocês todos são consoladores molestos, inoportunos" (16.2). Jó, porém, resiste, mesmo em meio à dor, à perseguição e à morte. Apesar de tudo, Jó proclama num ato de fé que parece carecer de toda razoabilidade humana: "Eu sei que meu redentor vivo e por fim se levantará sobre a terra. Depois, revestido este meu corpo da minha pele, em minha carne verei a Deus" (19.25s). Entretanto, diante de tal visão face a face - como escreveu Paulo em 1 Coríntios 13, Jó assume sua pequenez: "Eu te conhecia só de ouvir, mas agora os meus olhos te veem. Por isso me abomino e me arrependo no pó e na cinza" (42.5).

Algo extraordinário aconteceu nesse longo e sofrido embate pela relação verdadeira com Deus. Ver a Deus? Quem o consegue? Quem pode testemunhar a seu respeito? (Romanos 11.33ss). Se Jó nos pode ajudar, isso só se torna possível para quem aprende a partir do sofrimento, da dor e do clamor, próprio ou alheio, desde que tenhamos a ousadia de nos solidarizarmos com essas pessoas, povos, sociedades.

O teólogo tcheco Tomás Halík, numa reflexão contemporânea sobre o livro de Jó, igualmente ressalta a importância desse escrito e sua profunda contribuição para o

\footnotetext{
${ }^{36}$ GUTIÉRREZ, 1987, p. 161.

37 GUTIÉRREZ, 1987, p. 163.

${ }^{38}$ GUTIÉRREZ, 1987, p. 166.
} 
debate inescapável do mistério e da profundidade do mal no mundo. Halík relaciona a luta de Jó por sua inocência com o livro de Franz Kafka, O processo, no qual Josef K também proclama sua inocência diante de uma trama burocrática que mais parece um labirinto da insensatez. Jó não soube explicar as razões do seu sofrimento, mas ele experimentou algo da vida de Deus que não conhecia. E isso o levantou do pó e da cinza. A resposta é quase uma negação, mas é nessa descoberta paradoxal que uma réstia de esperança parece renascer para o velho e sofrido Jó. Halík, diferentemente de Gutiérrez, tira conclusões aparentemente estranhas. Ele escreve que, se Deus nos deu um mundo cheio de vida, faríamos bem em refletir exaustivamente sobre o que fizemos dele, ou o que fazemos dele hoje ou faremos no futuro. ${ }^{39}$ Os tempos que vivemos são maus e sem prenúncios de primaveras libertárias. Pior ainda é saber que grandes responsáveis por essa maldade se ocultam atrás de discursos e estruturas aparentemente inexpugnáveis. O mal se mostra com toda a sua carga sinistra ao ser onipresente, mas ocultar sua face. Mesmo diante dessa fatalidade, o livro de Jó ensina que podemos brigar com Deus, acusá-lo, chamá-lo, clamar por sua presença - não apesar do mal, mas precisamente no meio da maldade, como no caso de Jesus, naquela cruz do escândalo. É duro dar-se conta disso ao ler essa mensagem no livro das palavras divinas. Está lá para que não caiamos em falsas profecias, promessas ou esperanças vãs.

Na conclusão dessa reflexão sobre Jó, Halík faz uma constatação importante para esta reflexão sobre justiça humana e a justiça de Deus. Ele escreve: "Foi apenas em sua luta com Deus que Jó conseguiu transcender aquela postura de expectativa de comerciante", um sujeito mesquinho que constrói sua relação com Deus como uma troca comercial que funciona na base do crédito e do débito, postos na balança da vida. Esse tipo de teologia da retribuição, defendido por seus amigos, fizeram Jó se rebelar. Não pode ser assim. Eu não aceito. E nessa luta ele encontrou o Deus que estava disposto a escutá-lo, para além e contra débitos, créditos e esquemas de culpa. Jó se deparou com um Deus diferente, "que abarca o dia e a noite, o bem e o mal, a vida e a morte"40. É como canta o salmista de forma poética: "Para onde me ausentarei do teu Espírito? Para onde fugirei da tua face? Se subo aos céus, lá estás; se faço a minha cama no mais profundo abismo, lá estás também; se tomo as asas da alvorada e me detenho nos confins dos mares: ainda lá me haverá de guiar a tua mão. Se eu digo: As trevas, com efeito, me encobrirão, e a luz ao redor de mim se fará noite, até as próprias trevas não te serão escuras: as trevas e a luz são a mesma cousa" (Sl 139.7-12).

É uma experiência radical. E nessa radicalidade, uma luz tênue, uma brisa leve nos encobre de paz e bênção. E seguimos, ainda que coxos, como no confronto de Jacó com o anjo no vau do Jaboque (Gn 32.28-32). É em meio à luta com Deus e contra a injustiça que Deus se revela. É nela que se experimenta o Deus da esperança e da libertação. Nem antes, nem depois. Essa é a condição humana de quem crê "contra toda esperança" (Rm 4.18), como Abraão.

${ }^{39}$ HALÍK, Tomás. Não sem esperança. O retorno da religião em tempos pós-otimistas. Petrópolis: Vozes, 2018. p. 126s.

${ }^{40}$ HALÍK, 2018, p. 128. 
Na percepção de Jesus, porém, essa experiência tem um lugar e uma fonte: "Graças te dou, ó Pai do céu e da terra, porque ocultaste estas cousas aos sábios e entendidos, e as revelaste aos pequeninos. Sim, ó Pai, porque assim foi do teu agrado" (Mt 11.25s). Essa revelação continua a ser um mistério e um desafio para todos nós, para nossas igrejas e quem se define pela fé no crucificado. Quem terá a ousadia de contestá-lo? Não será melhor adotar a ousadia de admiti-la como caminho de vida e transformação? O Deus de Jesus se revela a partir do lado avesso do mundo. Eis uma boa formulação para a teologia da cruz hoje!

\section{Considerações finais}

Neste artigo, parti de um estudo da ideia de justiça humana que encontrei na obra de Amartya Sen, o economista que vem da Ásia e traz outra percepção para a elaboração desse tema. Sua contribuição me pareceu muito importante porque questiona teorias abstratas em relação aos temas da justiça e da injustiça que encontramos na vida social. Ele se vale de uma tradição alternativa ao que chamou de justiça transcendental e que se vincula, em primeiro lugar, ao estudo de instituições perfeitas. Sen defende uma abordagem comparativa que parte da vida real das pessoas, de seus comportamentos e interações sociais. Dessa forma, chega a conclusões relevantes para o enfrentamento das desigualdades e violências que caracterizam nossas sociedades atualmente. Essa ideia de justiça que parte de percepções valorativas plurais e concretas se torna um pressuposto importante para a formulação de políticas públicas que venham a mitigar as injustiças, antes de se buscar respostas ideais que jamais se concretizam.

Em seguida, procurei relacionar essa ideia de justiça com a teologia e a justiça de Deus, retomando o estudo da teologia da cruz de Lutero como aparece na obra de Vítor Westhelle: O Deus escandaloso. Westhelle foi um criterioso estudioso e conhecedor da teologia do reformador para a qual dedicou décadas de pesquisa. ${ }^{41}$ Como procurei retomar aqui o tema de seu livro, a teologia da cruz é um dos eixos centrais do pensamento de Lutero. E essa é uma teologia crítica que questiona respostas precárias e por vezes equivocadas para os dramas da vida e da relação com Deus. Westhelle argumenta que, para bem compreendermos o argumento de Lutero, é necessário tomar sua ideia da revelação de Deus a partir de suas máscaras. Como seres humanos, não temos acesso direto a Deus, mas sim indireto e de uma forma que faz balançar a racionalidade humana e sua autoconfiança. Ao manifestar-se sub contraria specie na cruz da condenação de Jesus, Deus se esconde e se revela ao mesmo tempo, mas como máscara. E isso ocorre em outros âmbitos da vida e da história.

Nas Teses de Heidelberg de 1518, Lutero fez afirmações contundentes sobre sua maneira de pensar que questionou a teologia escolástica, mesmo aceitando sua validade em certos âmbitos da vida humana. Diante de Deus, a teologia da cruz ensina não a pensar de forma abstrata e espiritual, antes é preciso ter a ousadia de "dizer

41 WESTHELLE, Vítor. Transfiguring Luther: the planetary promise of Luther's theology. Eugene, OR: Cascade Books, 2016. 
as coisas como elas são", ou como definiu Sen, olhar para a "vida como as pessoas a levam", a realizam concretamente, com suas contradições, acertos e erros.

E se esse é o princípio pelo qual a teologia se mostra relevante, o desafio maior é olhar para baixo, para quem sofre, clama e luta. No exemplo de Jó, referido aqui a partir do estudo crítico de Gustavo Gutiérrez, encontro um desafio radical na busca por um Deus que não se apresenta como um comerciante a contabilizar débitos e créditos, mas como um defensor dos pobres, oprimidos e inocentes, e que, ao escutar seu clamor, promete reerguer sua gente do pó e da cinza para uma vida com dignidade e sentido. Apenas fica o registro de que essa reviravolta não acontece como negação do mal e da injustiça, mas no meio da experiência da maldade, da fraqueza e da aparente derrota.

Na percepção de Jesus, o Crucificado que ressurgiu pela força de Deus, essa experiência tem um lugar e uma fonte como lemos no Evangelho de Mateus 11.25s: "Graças te dou, ó Pai do céu e da terra, porque ocultaste estas cousas aos sábios e entendidos, e as revelaste aos pequeninos. Sim, ó Pai, porque assim foi do teu agrado". Essa revelação continua a ser um mistério e um desafio para todas as pessoas de fé, para nossas igrejas e quem se define pela fé no crucificado, e mesmo para quem encontra sentido na vida simplesmente a partir da solidariedade humana livre e generosa. Quem terá a ousadia de contestar tal mistério? Não será melhor adotar a ousadia de admiti-lo como caminho de vida e transformação? O Deus de Jesus se revela a partir do lado avesso do mundo, escreveu Gutiérrez. Eis uma boa formulação para a teologia da cruz hoje! Essa teologia - bem entendida e posta em prática - contesta todas as formas de absolutismo e violência. Ela nos servirá como alento e encorajamento diante das muitas aporias que parecem por vezes nos derrotar. Ela nos desafia à parresía, à ousadia da fé que liberta. Não por acaso Lutero afirmou também que a justiça de Deus se manifestou no evangelho, na cruz, na fraqueza. E a partir dessa cruz, ela brilha em meio aos crucificados de todos os tempos, lugares e situações as mais absurdas. É na proximidade dessas pessoas que melhor compreenderemos quem é Deus e o que significa afirmar que ele é o "nosso defensor" (Jó).

\section{Referências}

AGAMBEN, Giorgio. Pilatos e Jesus. Florianópolis: UFSC; São Paulo: Boitempo, 2013.

ALTMANN, Walter. Lutero e a libertação. 2. ed. revista e ampliada. São Leopoldo: Sinodal; EST, 2016.

BEISE ULRICH, Claudete. A atuação e a participação das mulheres na Reforma protestante do século XVI. Estudos de Religião, v. 30, n. 2, p. 71-94, maio/ago. 2016.

BRUM, Eliane. Brasil - país construtor de ruínas. Um olhar sobre o Brasil, de Lula a Bolsonaro. Porto Alegre: Arquipélago, 2019.

COMIN - Conselho de Missão entre e com Povos Indígenas. A máscara índia de Deus. Cadernos do Comin, São Leopoldo, n. 1, 1982.

GUTIÉRREZ, Gustavo. Falar de Deus a partir do sofrimento do inocente. Uma reflexão sobre o livro de Jó. Trad. Lúcia Mathilde E. Orth. Petrópolis: Vozes, 1987.

HALÍK, Tomás. Não sem esperança. O retorno da religião em tempos pós-otimistas. Trad. Markus A. Hediger. Petrópolis: Vozes, 2018. 
HINKELAMMERT, Franz J. Cultura de la esperanza y sociedad sin exclusión. San José, Costa Rica: DEI, 1995.

LUTERO, Martinho. Obras selecionadas. São Leopoldo: Sinodal; Porto Alegre: Concórdia, 1987. v. 1.

. Obras selecionadas. São Leopoldo: Sinodal; Porto Alegre: Concórdia; Canoas: Ulbra, 2017. v. 13.

PINTO, Lúcio Flávio. Amazônia: o anteato da destruição. Belém: Grafisa. 1977. . Amazônia: no rastro do saque. São Paulo: Hucitec. 1980.

RIEGER, Joerg. Cristo e o império. De Paulo aos tempos pós-coloniais. Trad. Luiz Alexandre S. Rossi. São Paulo: Paulus, 2009.

SANTOS, Boaventura Sousa. O fim do império cognitivo. A afirmação das epistemologias do Sul. Belo Horizonte: Autêntica, 2019.

SCHÜSSLER-FIORENZA, Elisabeth. Discipulado de iguais. Uma ekklesiologia feminista de libertação. Trad. Yolanda Steidel Toledo. Petrópolis: Vozes, 1995.

SEN, Amartya. A ideia de justiça. Trad. Ricardo D. Mendes; Denise Bottmann. São Paulo: Cia. das Letras, 2011.

VALLEJO, Cesar. Poesia completa. Trad. Thiago de Mello. Rio de Janeiro: Philobiblion; Rioarte, 1984.

WESTHELLE, Vítor. O Deus escandaloso. O uso e abuso da cruz. Trad. Geraldo Korndörfer. São Leopoldo; Sinodal, EST, 2008.

. Transfiguring Luther: the planetary promise of Luther's theology. Eugene, OR: Cascade Books, 2016.

WESTHELLE, Vítor; ZWETSCH, Roberto E. (Eds.). Fides et ratio. Temas na teologia e filosofia suscitados por Lutero e a Reforma do século XVI. São Leopoldo: Sinodal; EST; ASTE, 2017. ZWETSCH, Roberto E. (Org.). Resgatando a radicalidade da Reforma. São Leopoldo: CEBI, 2019. 